Penelitian

\title{
Kualitas Spermatozoa dalam Modifikasi Pengencer Ringer Laktat Kuning Telur dengan Tambahan Astaxanthin dan Glutathione pada Tiga Jenis Ayam Lokal
}

\author{
(Sperm Quality in Lactate Ringer Egg Yolk Diluent Modified with of Astaxanthin and \\ Glutathione in Three Types Local Rooster) \\ Nila Pratiwi ${ }^{i^{*}}$, Tuty Laswardi Yusuf ${ }^{2}$, lis Arifiantini ${ }^{2^{*}}$, Cece Sumantri ${ }^{3}$ \\ ${ }^{1}$ Sekolah Pascasarjana, Institut Pertanian Bogor \\ ${ }^{2}$ Bagian Biologi Reproduksi, Departemen Klinik, Reproduksi, dan Patologi, Fakultas Kedokteran Hewan \\ ${ }^{3}$ Fakultas Peternakan, Institut Pertanian Bogor, Jln. Agatis, Dramaga, Bogor 16680 \\ *Penulis untuk korespondensi: pratiwi.nila@gmail.com \\ Diterima 22 Januari 2018, Disetujui 12 Juli 2018
}

\begin{abstract}
ABSTRAK
Tujuan penelitian ini adalah untuk menguji efek antioksidan astaxanthin dan glutathione dalam pengencer Ringer Laktat Kuning Telur (RL-KT) pada kualitas semen cair ayam merawang, SK kedu, dan kampung. Masing-masing 5 ekor ayam merawang, SK kedu, dan kampung, berumur 1-1,5 tahun digunakan sebagai sumber semen. Penelitian ini terdiri atas 2 tahap: (I) penelitian pertama bertujuan untuk menentukan dosis terbaik antioksoidan astaxanthin (0,004\%, $0,005 \%)$ dan glutathione (0,007\%, 0,008 \%) pada motilitas spermatozoa dengan menggunakan lima ekor ayam merawang. (II) penelitian kedua bertujuan menguji dosis antioksidan terbaik yang didapatkan dari penelitian pertama pada motilitas dan viabilitas spermatozoa pada 3 jenis ayam lokal. Hasil penelitian pertama menunjukkan tidak ada perbedaan pengaruh antara dosis astaxanthin dan glutathione dalam pengencer RL-KT yang disimpan selama 60 jam, namun spermatozoa pada dosis astaxanthin 0,004\% (3900 $\$ 3,3 \%$ ) menunjukkan motilitas yang lebih baik sehingga digunakan pada penelitian kedua. Hasil penelitian kedua menunjukkan bahwa penambahan astaxanthin $0,004 \%$ dapat mempertahankan motilitas spermatozoa yang disimpan sampai 36 jam pada ayam SK kedu $(40,10 \pm 1,33 \%)$ dan kampung (41,03 $\pm 2,44 \%)$ dan 24 jam pada ayam merawang $(46,41 \pm 4,42 \%)$. Viabilitas spermatozoa pada ketiga jenis ayam tergolong tinggi, yaitu berkisar antara $59,37 \pm 5,65 \%$ sampai $65,35 \pm 6,25 \%$. Dari data yang diperoleh, volume dan konsentrasi spermatozoa ayam merawang lebih tinggi dibandingkan SK kedu dan kampung. Semen diketahui mampu bertahan dalam waktu 36 jam pada pengencer RL-KT dengan penambahan astaxanthin 0,004\% dengan motilitas mencapai 40\%. Pengencer RL-KT yang ditambahkan astaxanthin 0,004\% menghasilkan rata-rata fertilitas spermatozoa sebesar $87 \%$.

Kata kunci: antioksidan, glutathione, astaxanthin, ringer laktat, spermatozoa, ayam lokal
\end{abstract}

\begin{abstract}
The aimed of this research was to determine the effects of astaxanthin and glutathione as antioxidants in Lactate Ringer - Egg Yolk (LR-EY) diluent on the quality of liquid semen in 3 types of local rooster. Five roosters from each breed of Merawang, Sentul Kampung Kedu (SK Kedu), and Kampung, aged 1-1,5 years were used as semen sources. This study consisted of 2 phases. The first experiment was designed to examine the optimum dose of astaxanthin (0,004\%, $0,005 \%$ and glutathione (0,007\%, 0,008\%) on the motilities of spermatozoa by using 5 merawang roosters. The second experiment was designed to examine the best diluents found in the first experiment on the the percentage of spermatozoa motility and viability in 3 types of roosters. The result of the first experiment showed that all doses of astaxanthin and glutathione in LR EY diluent had the same sperm motility in 60 hours observation ( $P>0,05)$, but $0,004 \%$ astaxanthin in LR-EY diluent showed the higher motility (39,00 $33,3 \%$ ) compared to other treatments. The result of the second experiment showed that the addition of $0.004 \%$ astaxanthin in LR-EY diluent could maintain the sperm motility until 36 hours in SK Kedu $(40,10 \pm 1,33 \%)$ and kampung $(41,03 \pm 2,44 \%)$ roosters, but in merawang rooster the sperm motility was $46,41 \pm 4,42 \%$ in 24 hours of storage. The sperm viability in 3 breeds were high $(59,37 \pm 5,65 \%$ until $65.35 \pm 6.25 \%$ ). It was concluded that sperm volume and concentration of merawang rooster were higher than SK kedu and kampung. The semen could be maintained over 36 hours on LR-EY diluent with the addition of $0.004 \%$ astaxanthin with $40 \%$ of motility. LR-EY diluent containing $0,004 \%$ astaxanthin had $87 \%$ of fertility.
\end{abstract}

Keywords: antioxidant, glutathione, astaxanthin, lactate ringer, spermatozoa, local rooster 


\section{PENDAHULUAN}

Berdasarkan data, hanya terdapat sekitar $23 \%$ populasi ayam lokal di Indonesia, $67 \%$ adalah ayam ras, sisanya adalah jenis unggas lain (Direktorat Jenderal Peternakan 2008). Beberapa jenis bangsa ayam lokal, seperti ayam kampung, merawang, dan sentul kampung kedu (SK kedu) sangat populer di masyarakat sebagai sumber bahan pangan protein. Ayam merawang memiliki spesifikasi khusus, warna bulunya seragam cokelat kemerahan dan keemasan mirip ayam ras petelur Rhode Island Red. Ayam merawang di samping merupakan plasma nutfah, juga mempunyai potensi baik untuk dikembangkan dan ditingkatkan produktivitasnya. Ayam SK kedu merupakan silangan dari 3 rumpun ayam lokal Indonesia, yaitu ayam jantan sentul dikawinkan dengan ayam betina kampung kemudian hasil dari perkawinan tersebut dikawinkan lagi dengan ayam betina kedu.

Penampilan fisik dan ciri khas ayam SK kedu adalah bulu yang didominasi oleh warna hitam berkilauan, kuning, putih, merah kecokelatan, dan hijau. Ayam sentul berasal dari wilayah Ciamis Jawa Barat, mempunyai keunggulan penghasil daging dan telur dengan produksi telur 118 butir/tahun (Diwyanto et al., 2011). Ayam kedu berasal dari daerah Kedu, Kabupaten Temanggung dan memiliki keunggulan sebagai produksi telur tinggi, yaitu 123,9 butir/tahun. Ayam kampung merupakan ayam asli Indonesia yang telah lama dipelihara dan merupakan salah satu anggota dari ayam lokal yang sangat potensial di Indonesia dengan produksi telur 80 butir/induk/tahun.

Perkembangbiakan ayam lokal hanya berjalan secara alami sehingga mutunya kurang baik. Berbagai cara terus diupayakan dalam meningkatkan populasi dan produksi ternak salah satunya dengan penerapan teknologi Inseminasi Buatan (IB). Teknologi IB diharapkan dapat meningkatkan nilai genetik dan populasi ayam lokal. Semen yang digunakan untuk IB dapat berupa semen beku atau semen cair. Semen beku atau semen cair harus berasal dari pejantan yang telah diseleksi libido (keinginan kawin) dan kualitas semen yang baik.

Peranan bahan pengencer mampu melindungi spermatozoa dari cekaman dingin (cold shock), menyediakan suatu penyangga untuk mencegah perubahan $\mathrm{pH}$ dan memperbanyak volume semen sehingga lebih banyak hewan betina yang dapat diinseminasi. Kuning telur mengandung asam-asam amino, karbohidrat, vitamin, dan mineral untuk kebutuhan hidup spermatozoa.
Proses pengenceran semen memicu pembentukan reaksi oksidatif berupa Reactive Oxygen Species (ROS) yang dapat menurunkan kualitas semen. Pembentukan ROS dapat diminimalkan dengan menambahkan antioksidan pada pengencer semen. Beberapa antioksidan telah ditambahkan ke dalam bahan pengencer di antaranya glutathione dan astaxanthin. Glutathione telah digunakan sebagai antioksidan pada semen beku sapi (Chatterjee et al., 2001; Syarifuddin et al., 2012), semen beku domba (Uysal \& Bucak, 2007), dan semen beku babi (Whitaker et al., 2008). Astaxanthin juga telah digunakan pada semen beku sapi (Farzan et al., 2014), pada pria infertil (Comhaire et al., 2005), dan pada semen ayam kampung dan ayam hutan hijau (Octa et al., 2014; Bebas et al., 2016). Penelitian ini bertujuan untuk menganalisis kualitas semen dari tiga jenis ayam (merawang, SK kedu, dan kampung), serta pengaruh penambahan antioksidan astaxanthin dan glutathione dalam pengencer ringer laktat kuning telur.

\section{BAHAN DAN METODE}

\section{Bahan Penelitian}

Semen segar yang digunakan bersumber dari tiga rumpun pejantan ayam lokal berjumlah lima belas ekor, yaitu lima ekor ayam kampung, lima ekor ayam SK kedu, dan lima ekor ayam merawang dengan umur $\pm 1-1,5$ tahun (dewasa kelamin) dan bobot badan rata-rata $1,5-2 \mathrm{~kg}$. Untuk keperluan IB digunakan ayam arab betina berjumlah tiga ekor. Koleksi semen dilakukan dua kali seminggu. Semen yang memenuhi syarat adalah semen dengan konsentrasi lebih dari $3000 \times 10^{6}$, motilitas lebih dari $80 \%$, dan abnormalitas kurang dari $10 \%$.

Ayam percobaan dipelihara pada kandang individu dengan masing-masing kandang dilengkapi tempat pakan dan minum. Pemberian pakan dan minum dilakukan setiap hari pada pagi dan sore hari. Jumlah pakan yang diberikan adalah 100 gram/ekor dengan komposisi protein kasar $18 \%$. Ayam betina yang digunakan adalah ayam betina arab yang mempunyai tubuh sehat dan telah mencapai masa dewasa kelamin atau siap untuk dilakukan IB. Dosis IB yang digunakan adalah 100 juta spermatozoa dengan volume $0,25 \mathrm{~mL}$. Penelitian dibagi menjadi 2 tahap, yaitu: (1) Penentuan dosis Ringer Laktat Kuning Telur (RLKT)-astaxanthin dan RLKTglutathione dalam mempertahankan motilitas spermatozoa ayam merawang. (2) Daya tahan 
spermatozoa ayam merawang, SK kedu, dan kampung dalam pengencer RLKT-astaxanthin $0.004 \%$.

Tahap I Penentuan Dosis RLKT-Astaxanthin dan RLKT-Glutathione dalam Mempertahankan Motilitas Spermatozoa Ayam Merawang

Semen diambil dari lima ekor ayam merawang dan diencerkan RL-KT dengan tambahan astaxanthin $(0,004 \%, 0,005 \%)$ dan glutathione (0,007\%, $0,008 \%)$, kemudian dibandingkan dengan pengencer RL-KT tanpa antioksidan sebagai kontrol. Pengamatan dilakukan tiap 12 jam pada persentase motilitas spermatozoa.

\section{Persiapan media pengencer}

Larutan RL-KT dibuat dengan cara mencampur ringer laktat (RL) dengan kuning telur (KT) (Tabel 1), larutan dihomogenkan menggunakan magnetic stirrer selama 10 menit, disentrifugasi pada kecepatan 3000 x g selama 15 menit.

Tabel 1 Komposisi Larutan Ringer Laktat Kuning Telur

\begin{tabular}{lc}
\hline \multicolumn{1}{c}{ Bahan } & $\mathrm{mL}$ \\
\hline Ringer Laktat $(\mathrm{mL})$ & 80,00 \\
Kuning Telur $(\mathrm{mL})$ & 20,00 \\
$\mathrm{pH}$ & 6,8 \\
\hline Total $(\mathrm{mL})$ & 100,00 \\
\hline
\end{tabular}

Tabel 2 Komposisi Ringer Laktat Kuning Telur Astaxanthin dengan Konsentrasi Berbeda

\begin{tabular}{lcc}
\hline \multicolumn{1}{c}{ Bahan penyusun } & RLKT-A & RLKT-A \\
\hline RL-KT (\%) & 100 & 100 \\
Astaxanthin (\%) & 0,004 & 0,005 \\
Penisilin (IU mL ${ }^{-1}$ ) & 1000 & 1000 \\
Streptomisin (IU mL 1 ) & 1 & 1 \\
\hline \multicolumn{2}{l}{ Ket: RLKT-A = Ringer Laktat Kuning Telur-Astaxanthin }
\end{tabular}

Ket: RLKT-A = Ringer Laktat Kuning Telur-Astaxanthin

Penelitian ini menggunakan modifikasi pengencer RL-KT dengan dosis astaxanthin (0,004\%, 0,005\%) dan glutathione $(0,007 \%, 0,008 \%)$ serta penambahan antibiotik penisilin dan streptomisin pada masingmasing larutan pengencer.

Tabel 3 Komposisi RL-KT glutathione dengan konsentrasi berbeda

\begin{tabular}{lll}
\hline \multicolumn{1}{c}{ Bahan penyusun } & RLKT-G & RLKT-G \\
\hline RL-KT (\%) & 100 & 100 \\
Glutathione $(\%)$ & 0,007 & 0,008 \\
Penisilin (IU mL 1 ) & 1000 & 1000 \\
Streptomisin (IU mL 1 ) & 1 & 1 \\
\hline Ket: RLKT-G= Ringer Laktat Kuning Telur-Glutathione
\end{tabular}

\section{Koleksi dan evaluasi semen}

Pada tahap ini hanya digunakan jenis ayam merawang. Semen dikoleksi dengan teknik pemijatan pada daerah kloaka sampai terjadi pengeluaran semen. Setelah semen dikoleksi kemudian dievaluasi secara makroskopis dan mikroskopis.

Evaluasi secara makroskopis meliputi volume, warna, konsistensi, dan derajat keasaman, Volume semen diukur menggunakan pipet $1 \mathrm{ml}$ yang dilengkapi pipet filter. Warna diamati secara visual (keputihan, putih susu, dan krem). Konsistensi dievaluasi dengan memiringkan tabung dan mengembalikan ke posisi semula (sedang, kental). Derajat keasamaan $(\mathrm{pH})$ diukur menggunakan kertas indikator $\mathrm{pH}$.

Evaluasi secara mikroskopis meliputi gerakan massa, motilitas spermatozoa, dan viabilitas spermatozoa, morfologi spermatozoa, dan konsentrasi spermatozoa. Gerakan massa dievaluasi dengan cara meneteskan semen di atas gelas objek, diamati di bawah mikroskop pada pembesaran $10 \times 10$, dengan penilaian sangat baik (+++), baik (++), lumayan (+), dan buruk (0). Motilitas spermatozoa dievaluasi dengan cara mencampur satu tetes semen dengan $\mathrm{NaCl}$ fisiologis secukupnya, diletakkan pada gelas objek. Selanjutnya diamati di bawah mikroskop dengan pembesaran $40 \times 10$. Motilitas dinilai dengan melihat perbandingan antara spermatozoa yang bergerakan progresif dengan gerakan spermatozoa yang lain pada lima lapang pandang, nilai motilitas dinyatakan dalam persen.

Viabilitas spermatozoa diamati dengan cara membuat preparat ulas. Masing-masing satu tetes semen dan pewarna eosin nigrosin dihomogenkan, lalu diulas di atas gelas objek kemudian dikeringkan. Preparat diperiksa di bawah mikroskop dengan pembesaran 40x10. Spermatozoa dihitung pada sepuluh lapang pandang dengan jumlah minimal 200 sel spermatozoa. Spermatozoa yang hidup tidak menyerap warna, sedangkan spermatozoa yang mati menyerap warna merah ungu. Morfologi spermatozoa dihitung dengan mengamati spermatozoa yang normal dan abnormal minimal 200 sel spermatozoa pada sepuluh lapang pandang di bawah mikroskop pembesaran $40 \times 10$. Konsentrasi spermatozoa per $\mathrm{mL}$ dihitung menggunakan kamar hitung Neubauer. Semen diencerkan 500 kali (998 $\mu \mathrm{L}$ formolsalin dan $2 \mu \mathrm{L}$ semen). Jumlah spermatozoa dari lima kotak hitung Neubauer diamati di bawah mikroskop pembesaran $40 \times 10$ dan jumlah sel spermatozoa dikalikan $25 \times 10^{6}$. 
Pengenceran semen dan penambahan antioksidan

Syarat suatu pengenceran adalah spermatozoa dengan konsentrasi lebih dari $3000 \times 10^{6}$, motilitas lebih dari $80 \%$, dan abnormalitas kurang dari $10 \%$. Dosis konsentrasi yang digunakan sebesar $100 \times 10^{6}$ dan dosis volume sebesar $0,25 \mathrm{~mL}$.

\section{Volume $x$ Konsentrasi $x$ Motilitas}

\section{Dosis Konsentrasi}

Masing-masing tabung ditambahkan dengan pengencer RL-KT lalu ditambahkan antioksidan astaxanthin (0,004\%, 0,005\%) dan glutathione $(0,007 \%, 0,008 \%)$. Satu tabung tanpa tambahan antioksidan dibuat sebagai kontrol. Pengamatan dilakukan terhadap motilitas spermatozoa setiap 12 jam sekali. Dosis terbaik antioksidan digunakan pada Tahap II. Semen yang berasal dari lima ekor ayam merawang, dicampur menjadi satu, kemudian dibagi ke dalam lima tabung dengan volume yang sama.

Tahap II Daya tahan spermatozoa ayam merawang, SK kedu, dan kampung dalam pengencer RLKT-Astaxanthin 0,004\%

Pengamatan Tahap II ini menggunakan semen dari tiga jenis ayam lokal berjumlah 15 ekor, yaitu lima ekor merawang, lima ekor SK kedu, dan lima ekor kampung. Semen dikoleksi dan dievaluasi seperti pada tahap I. Semen hasil koleksi kemudian diencerkan dengan RL-KT ditambah astaxanthin 0.004\% dosis terbaik yang didapatkan dari Tahap I. Semen yang telah diencerkan kemudian disimpan dalam refrigerator $\left(4-5^{\circ} \mathrm{C}\right)$. Pengamatan dilakukan terhadap persentase motilitas dan viabilitas spermatozoa setiap 12 jam sekali hingga mencapai 60 jam.

\section{Analisis Data}

Semua data yang diperoleh dianalisis menggunakan Rancangan Acak Lengkap (RAL), jika terdapat perbedaan dilakukan uji lanjut Duncan dengan selang kepercayaan $95 \%$.

\section{HASIL PENELITIAN}

Tahap I Penentuan Dosis RLKT-Astaxanthin dan RLKT-Glutathione dalam Mempertahankan Motilitas Spermatozoa Ayam Merawang

Kualitas semen segar ayam merawang menunjukkan volume semen $0,35 \pm 0.07 \mathrm{~mL}$ berwarna putih susu dengan konsistensi semen kental. Nilai $\mathrm{pH}$ semen yang diperoleh adalah $6,95 \pm 0,01$. Evaluasi mikroskopis semen segar ayam merawang menunjukkan nilai gerakan massa spermatozoa yang sangat baik (+++). Motilitas spermatozoa menunjukkan nilai $81,80 \pm 1,37 \%$ dengan viabilitas spermatozoa sangat tinggi, yaitu $92,61 \pm$ 1,93\%. Abnormalitas spermatozoa menunjukkan nilai $2,59 \pm 0,20 \%$ dan konsentrasi spermatozoa adalah $4240 \pm 134$ juta/mL (Tabel 4).

Hasil penelitian menunjukkan bahwa motilitas spermatozoa ayam merawang yang disimpan selama 60 jam berkisar antara 4,00 $\pm 1,0 \%$ sampai $21,00 \pm 5,1 \%$, di mana spermatozoa yang ditambah dosis astaxanthin 0,004\% memiliki motilitas lebih tinggi $(21,00 \pm 5,1 \%)$ dibandingkan dengan dosis astaxanthin 0,005\%, glutathione 0,007\%, dan glutathione $0,008 \%$. Pengamatan motilitas sebesar $\pm 40 \%$ bertahan pada jam ke-36 dalam dosis astaxanthin $0,004 \%$, di mana motilitasnya menunjukkan tidak berbeda nyata dibanding kontrol $(P<0,05)$, sedangkan pada pengencer lainnya, yaitu astaxanthin 0,005\%, glutathione 0,007\%, dan glutathione 0,008\% hanya bertahan selama 24 jam (Tabel 5). Dosis

Tabel 4 Kualitas Semen Segar Ayam Merawang

\begin{tabular}{ll}
\hline \multicolumn{1}{c}{ Parameter } & Rataan \pm SEM \\
\hline Makroskopis & \\
Volume $(\mathrm{mL})$ & $0.35 \pm 0.07$ \\
Warna & Putih susu \\
Konsistensi & Kental \\
pH & $6.95 \pm 0.01$ \\
Mikroskopis & \\
Gerakan Massa & +++ \\
Motilitas spermatozoa $(\%)$ & $81.80 \pm 1.37$ \\
Viabilitas spermatozoa $(\%)$ & $92.61 \pm 1.93$ \\
Abnormalitas spermatozoa $(\%)$ & $2.59 \pm 0.20$ \\
Konsentrasi spermatozoa $\left(\mathrm{x} 10^{6} \mathrm{sel} / \mathrm{mL}\right)$ & $4240 \pm 134$ \\
\hline
\end{tabular}


Tabel 5 Rataan Motilitas Spermatozoa Ayam Merawang dalam Pengencer RL-KT dengan Perbandingan Dosis Astaxanthin dan Glutathione

\begin{tabular}{cccccc}
\hline Waktu pengamatan & Kontrol & $\begin{array}{c}\text { Astaxanthin } \\
0,004 \%\end{array}$ & $\begin{array}{c}\text { Astaxanthin } \\
0,005 \%\end{array}$ & $\begin{array}{c}\text { Glutathione } \\
0,007 \%\end{array}$ & $\begin{array}{c}\text { Glutathione } \\
0,008 \%\end{array}$ \\
\hline 0 jam & $72,00 \pm 8,3$ & $77,00 \pm 2,0$ & $78,00 \pm 2,0$ & $77,00 \pm 2,0$ & $70,00 \pm 5,2$ \\
12 jam & $63,00 \pm 7,6$ & $62,00 \pm 2,0$ & $64,00 \pm 3,1$ & $63,00 \pm 5,1$ & $61,00 \pm 4,3$ \\
24 jam & $54,00 \pm 5,3$ & $49,00 \pm 3,3$ & $49,00 \pm 4,8$ & $49,00 \pm 4,5$ & $46,00 \pm 4,0$ \\
36 jam & $42,00 \pm 5,6$ & $39,00 \pm 3,3$ & $30,00 \pm 4,1$ & $33,00 \pm 3,0$ & $36,00 \pm 1,8$ \\
48 jam & $27,00 \pm 5,6$ & $29,00 \pm 5,7$ & $22,00 \pm 4,6$ & $20,00 \pm 4,1$ & $18,00 \pm 2,5$ \\
60 jam & $18,00 \pm 3,3$ & $21,00 \pm 5,1$ & $15,00 \pm 2,7$ & $16,00 \pm 4,0$ & $4,00 \pm 1,0$ \\
\hline
\end{tabular}

astaxanthin $\quad 0,004 \%$ menunjukkan lama penyimpanan yang sedikit lebih lama dibanding kontrol, yaitu 36 jam, sehingga dipilih untuk digunakan pada Tahap II.

Tahap II Daya Tahan Spermatozoa Ayam Merawang, SK Kedu, dan Kampung dalam Pengencer RLKT-Astaxanthin 0,004\%

Pemeriksaan makroskopis pada ketiga jenis ayam menunjukkan volume semen ayam merawang $(0,42 \pm 0,04 \mathrm{~mL})$ yang lebih tinggi $(P<0,05)$ dibandingkan ayam kampung $(0,23 \pm 0,01 \mathrm{~mL})$ dan $\mathrm{SK}$ kedu $(0,16 \pm 0,01 \mathrm{~mL})$. Menurut Sopiyana et al. (2006) ayam kampung memiliki volume semen sebesar $0,28 \pm 0,05 \mathrm{~mL}$. Volume semen yang diperoleh dalam penelitian ini sama dengan volume semen yang diperoleh dari penelitian Siudzinska \& Lukaszewicz (2008) pada jenis ayam Green Legged Partridge, Black Minorc, White Crested Black Polish, dan Italian Partridge, yaitu berkisar dari 0,24 sampai 0,52 mL. Perbedaan volume ejakulat menurut Donoghue \& Wishart (2000) dapat dipengaruhi oleh jenis, umur, individu, lingkungan, dan musim. Ketiga jenis ayam menunjukkan warna semen putih susu, konsistensi kental, dan $\mathrm{pH}$ berkisar antara $6,95 \pm 0,02$ sampai $6,97 \pm 0,04$.

Pemeriksaan makroskopis menunjukkan gerakan massa baik dengan kategori +++. Motilitas spermatozoa berkisar antara $82,10 \pm 0,89 \%$ sampai $83,20 \pm 0,86 \%$. Motilitas ketiga jenis ayam lebih tinggi dibanding semen ayam kampung berdasarkan laporan Wiyanti et al. (2013) sebesar $77 \%$. Viabilitas spermatozoa berkisar antara $90,67 \pm 7,22 \%$ sampai $92,03 \pm 0,20 \%$.

Ketiga jenis ayam menunjukkan abnormalitas kurang dari $10 \%$, yang berkisar antara 3,00 $\pm 0,45 \%$ sampai $4,31 \pm 0,76 \%$ (Tabel 6). Ayam kampung memiliki abnormalitas tertinggi $(4,31 \pm 0,76 \%)$ dibandingkan ayam SK kedu $(3,00 \pm 0,45 \%)$ dan merawang $(3,23 \pm 0,70 \%)$. Perbedaan abnormalitas antara jenis ayam disebabkan oleh ketidakseimbangan antara nutrisi dan endokrin (Arifiantini et al., 2005).

Konsentrasi spermatozoa antara ketiga jenis ayam menunjukkan perbedaan. Ayam merawang memiliki konsentrasi tertinggi $(4568 \pm 272$ juta $/ \mathrm{mL})$ diikuti oleh ayam SK kedu (3622 \pm 265 juta/mL) dan terendah ayam kampung $(2998 \pm 265$ juta/mL). Berdasarkan laporan Sopiyana et al. (2006), konsentrasi spermatozoa ayam kampung yang diperoleh memiliki konsentrasi lebih kecil, yaitu hanya sebesar $1,355 \pm 128$, sedangkan berdasarkan laporan Saleh \& Sugiyatno (2007) kosentrasi spermatozoa ayam kampung yang diperoleh sebesar

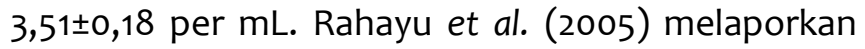
konsentrasi semen ayam merawang yang diperoleh lebih kecil, yaitu hanya sebesar $2,9 \times 10^{9}$ spermatozoa/mL. Malik et al. (2013) menyatakan perbedaan konsentrasi spermatozoa ayam disebabkan oleh faktor pakan, bobot badan, dan jenis. Jenis ayam yang besar umumnya memiliki konsentrasi spermatozoa yang tinggi (Donoghue \& Wishart, 2000).

Hasil penelitian menunjukkan bahwa semen pada ketiga jenis ayam (merawang, SK kedu, dan kampung) dalam bahan pengencer RL-KT yang telah dimodifikasi dengan penambahan astaxanthin $0,004 \%$ terlihat bahwa ayam kampung memiliki motilitas terbaik $(22,23 \pm 4,92 \%)$ dengan viabilitas sebesar $34,70 \pm 1,32 \%$ dalam penyimpanan selama 60 jam (Tabel 7).

Hasil penelitian berdasarkan motilitas $\pm 40 \%$, semen yang bertahan pada penyimpanan tiga puluh enam jam dalam pengencer RL-KT dengan astaxanthin $0,004 \%$ ialah ayam SK kedu $(40,10 \pm 1,33 \%)$ dengan viabilitas sebesar $59,37 \pm 5,65 \%$ dan kampung $(41,03 \pm 2,44 \%)$ dengan viabilitas sebesar $60,04 \pm 0,81 \%$. Semen ayam merawang hanya bertahan pada penyimpanan dua puluh empat jam, dengan motilitas sebesar $46,41 \pm 4,42 \%$, dan viabilitas sebesar $65,35 \pm 6,25 \%$ (Tabel 7). 
Tabel 6 Karakteristik Semen Segar Ayam Merawang, SK Kedu, Kampung

\begin{tabular}{llll}
\hline \multicolumn{1}{c}{ Parameter } & Merawang & SK Kedu & Kampung \\
\hline Makroskopis & & & $0,23 \pm 0,01 \mathrm{c}$ \\
Volume $(\mathrm{mL})$ & $0,42 \pm 0,04 \mathrm{a}$ & $0,16 \pm 0,01 \mathrm{~b}$ & Putih susu \\
Warna & Putih susu & Putih susu & Kental \\
Konsistensi & Kental & Kental & $6,97 \pm 0,04$ \\
pH & $6,95 \pm 0,02$ & $6,95 \pm 0,03$ & +++ \\
Mikroskopis & & & $82,10 \pm 0,89$ \\
Gerakan Massa & +++ & +++ & $90,67 \pm 7,22$ \\
Motilitas spermatozoa (\%) & $82,18 \pm 0,97$ & $83,20 \pm 0,86$ & $4,31 \pm 0,76 \mathrm{a}$ \\
Viabilitas spermatozoa (\%) & $90,82 \pm 1,16$ & $92,03 \pm 0,20$ & $2998 \pm 265 \mathrm{C}$ \\
Abnormalitas spermatozoa (\%) & $3,23 \pm 0,70 \mathrm{ab}$ & $3,00 \pm 0,45 \mathrm{ab}$ & $3622 \pm 265 \mathrm{~b}$ \\
Konsentrasi spermatozoa (10 $6 \mathrm{sel})$ & $4568 \pm 272 \mathrm{a}$ & & \\
\hline
\end{tabular}

Ket: Huruf berbeda yang mengikuti angka pada baris yang sama menunjukkan berbeda nyata $(\mathrm{P}<0,05)$

Tabel 7 Daya Hidup Spermatozoa Tiga Jenis Ayam dalam Pengencer RL-KT dengan Tambahan Astaxanthin 0.004\%

\begin{tabular}{cllllll}
\hline \multirow{2}{*}{$\begin{array}{c}\text { Waktu } \\
\text { pengamatan }\end{array}$} & \multicolumn{3}{c}{ Motilitas (\%) } & \multicolumn{2}{c}{ Viabilitas (\%) } \\
\cline { 2 - 7 } & Merawang & SK Kedu & Kampung & Merawang & SK Kedu & Kampung \\
\hline 0 jam & $80,00 \pm 1,07$ & $81,85 \pm 0,64$ & $78,68 \pm 0,55$ & $93,25 \pm 1,04$ & $94,01 \pm 0,02$ & $92,84 \pm 1,05$ \\
12 jam & $57,58 \pm 5,56$ & $67,50 \pm 1,70$ & $64,70 \pm 2,33$ & $80,74 \pm 2,85$ & $85,26 \pm 4,08$ & $85,89 \pm 2,08$ \\
24 jam & $\mathbf{4 6 , 4 1 \pm 4 , 4 2}$ & $51,45 \pm 1,82$ & $49,96 \pm 1,93$ & $\mathbf{6 5 , 3 5 \pm 6 , 2 5}$ & $\mathbf{7 3 , 8 9 \pm 4 , 7 5}$ & $75,22 \pm 1,44$ \\
36 jam & $36,91 \pm 4,46$ & $\mathbf{4 0 , 1 0 \pm 1 , 3 3}$ & $\mathbf{4 1 , 0 3 \pm 2 , 4 4}$ & $55,68 \pm 4,55$ & $\mathbf{5 9 , 3 7 \pm 5 , 6 5}$ & $\mathbf{6 0 , 0 4 \pm 0 , 8 1}$ \\
48 jam & $26,33 \pm 5,13$ & $29,15 \pm 1,42$ & $31,56 \pm 4,24$ & $39,91 \pm 7,27$ & $50,02 \pm 7,72$ & $41,52 \pm 4,00$ \\
60 jam & $14,83 \pm 2,65$ & $19,40 \pm 1,74$ & $22,23 \pm 4,92$ & $30,76 \pm 3,49$ & $40,50 \pm 5,03$ & $34,70 \pm 1,32$ \\
\hline
\end{tabular}

Daya hidup spermatozoa ketiga jenis ayam mengalami penurunan selama penyimpanan. Penambahan astaxanthin pada preservasi semen ayam dalam penelitian ini tidak terbukti dapat memperbaiki kualitas semen. Namun demikian, pada semen beku sapi, penambahan astaxanthin $0,5 \mu \mathrm{M}$ mampu memperbaiki motilitas spermatozoa (Farzan et al., 2014). Penelitian lain, pada pengencer glukosa $0.6 \%$ yang ditambahkan astaxanthin 0,004\% menunjukkan motilitas spermatozoa yang lebih baik pada semen cair ayam kampung yang disimpan selama 108 jam (Octa et al., 2014). Semen ayam hutan hijau pada pengencer laktosa $0,6 \%$ yang ditambahkan astaxanthin $0,004 \%$ juga menunjukkan motilitas spermatozoa terbaik pada 48 jam penyimpanan (Bebas et al., 2016). Glukosa dan laktosa merupakan karbohidrat sederhana yang dapat digunakan oleh spermatozoa untuk energi. Penelitian ini tidak menggunakan tambahan karbohidrat sehingga motilitasnya tidak lebih baik.

\section{PEMBAHASAN}

Tahap I Penentuan dosis RLKT-Astaxanthin dan RLKT-Glutathione dalam Mempertahankan Motilitas Spermatozoa Ayam Merawang

Getachew (2016) melaporkan umumnya kualitas semen ayam lokal mempunyai volume rata-rata an- tara 0,2 sampai $0,5 \mathrm{~mL}$, pH berkisar mulai dari 7,2 sampai 7,6 . Motilitas sebesar 60 sampai $80 \%$ dengan viabilitas berkisar antara 85 sampai $90 \%$. Tabatabaei et al. (2009) juga melaporkan bahwa motilitas semen ayam lokal pada umumnya sebesar $86,5 \pm 0,78 \%$ dengan viabilitas sebesar $89,63 \pm 1,32 \%$, sedangkan berdasarkan laporan penelitian Rakha et al (2015), motilitas spermatozoa pada spesies Red Jungle Fowl hanya sebesar $63,5 \pm 4,0 \%$ dengan viabilitas sebesar $92,4 \pm 0,8 \%$.

Secara umum, sel spermatozoa terdiri atas kepala, badan, dan ekor. Bagian kepala berisi inti sel, yang di dalamnya terkandung materi genetik (Tuncer et al., 2006), sedangkan gambaran spermatozoa normal pada spesies ayam adalah berbentuk seperti jarum dengan bagian kepala dan badan panjang serta lebih tebal. Getachew (2016) melaporkan bahwa bagian kepala spermatozoa ayam berbentuk panjang, jika dibandingkan dengan spesies lain.

Spermatozoa mati ditandai dengan bagian kepala yang menyerap warna dari pewarna eosin nigrosin. Spermatozoa abnormal ditandai dengan bentuk badan yang melengkung (Gambar 1). Bentuk abnormalitas yang ditemukan masuk ke dalam kategori abnormalitas sekunder, yaitu hilangnya ekor, ekor melingkar, dan ekor patah. Menurut Alkan et al. (2001), kerusakan morfologi spermatozoa ayam 


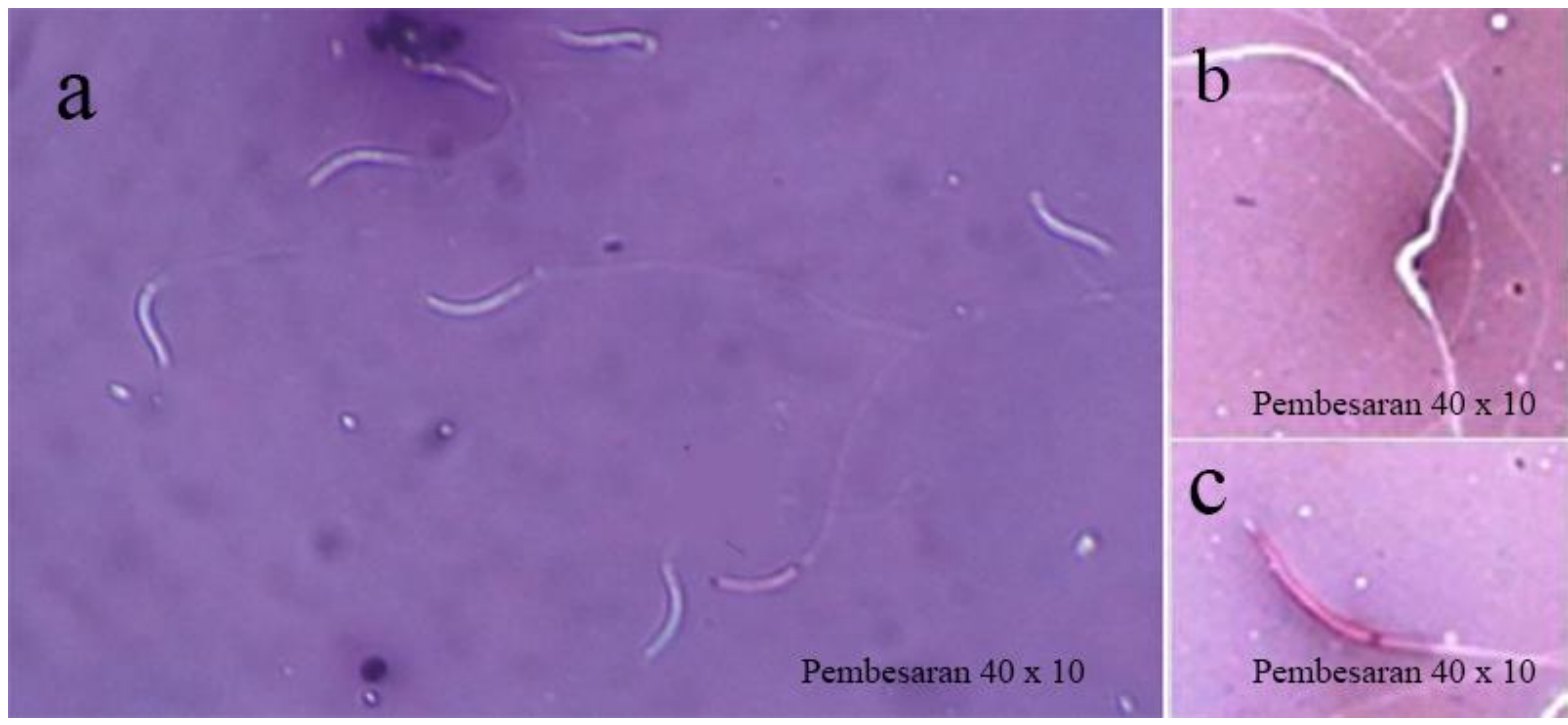

Gambar 1 Spermatozoa dalam Pewarnaan Eosin-nigrosin, Menampilkan (a) Spermatozoa Hidup; (b) Spermatozoa Mati; (c) Spermatozoa Abnormal

yang umum terjadi adalah bagian leher yang membengkok, bagian badan yang rusak (bengkok, bengkak, melilit, dan melingkar).

Antioksidan adalah senyawa atau zat yang dapat menghambat, menunda, mencegah, atau memperlambat reaksi oksidasi meskipun dalam kosentrasi yang kecil. Peranan antioksidan sangat berpengaruh selama proses penyimpanan semen. Salah satu fungsi antioksidan yang ditambahkan ke dalam bahan pengencer ialah dapat menjaga morfologi spermatozoa agar tetap utuh dan juga dapat mempertahankan daya hidup spermatozoa dalam waktu yang lebih lama. Namun, penggunaan antioksidan tidak selalu meningkatkan motilitas spermatozoa.

Berdasarakan hasil penelitian, penambahan berbagai konsentrasi antoksidan pada bahan pengencer tidak menunjukkan perbedaan nyata pada semen cair. Penelitian Rizal \& Herdis (2010) melaporkan bahwa penambahan senyawa antioksidan, antara lain vitamin $C$, vitamin $E$, glutation, dan $\beta$ karoten ke dalam pengencer mampu meningkatkan kualitas semen beku berbagai hewan ternak.

Astaxanthin adalah pigmen karotenoid yang larut dalam lemak dan terletak di membran sel. Astaxanthin bekerja dengan cara mengurangi proses peroksidasi lemak (Ambati et al., 2014). Astaxanthin mengandung ikatan rangkap terkonjugasi, termasuk dalam kelompok hidroksil dan keto, memiliki sifat lipofilik maupun hidrofil. Warna merah pada bubuk astaxanthin berasal dari ikatan rangkap terkonjugasi yang bertindak sebagai antioksidan yang kuat. Bekerja dengan cara menyumbang elektron dan bereaksi untuk mengkonversi radikal bebas menjadi produk yang lebih stabil dan menghentikan reaksi be- rantai dari radikal bebas. Farzan et al. (2014) melaporkan bahwa penambahan $2 \mu \mathrm{M}$ antioksidan astaxanthin pada bahan pengencer dapat melindungi sel spermatozoa dari kerusakan sel. Thananurak et al. (2015) mengemukakan bahwa penambahan antioksidan dengan dosis yang sesuai dapat secara signifikan menghambat terjadinya ROS.

Secara umum dapat dikatakan bahwa penggunaan konsentrasi antioksidan yang sesuai, selain mewarisi sifat antioksidan juga tidak akan menyebabkan kerusakan pada spermatozoa dan dapat dengan aman digunakan sebagai bahan pengencer spermatozoa.

Tahap II Daya Tahan Spermatozoa Ayam Merawang, SK Kedu, dan kampung dalam Pengencer RLKT-Astaxanthin 0,004\%

Daya hidup spermatozoa yang dihasilkan ketiga jenis ayam mengalami penurunan selama penyimpanan. Penambahan astaxanthin pada preservasi semen ayam dalam penelitian ini tidak terbukti dapat memperbaiki kualitas semen. Namun demikian, pada semen beku sapi, penambahan astaxanthin $0,5 \mu \mathrm{M}$ mampu memperbaiki motilitas spermatozoa (Farzan et al., 2014). Penelitian lain, pada pengencer glukosa $0,6 \%$ yang ditambahkan astaxanthin 0,004\% menunjukkan motilitas spermatozoa yang lebih baik pada semen cair ayam kampung yang disimpan selama 108 jam (Octa et al., 2014). Semen ayam hutan hijau pada pengencer laktosa $0,6 \%$ yang ditambahkan astaxanthin $0,004 \%$ juga menunjukkan motilitas spermatozoa terbaik pada 
48 jam penyimpanan (Bebas et al., 2016). Glukosa dan laktosa merupakan karbohidrat sederhana yang dapat digunakan oleh spermatozoa sebagai sumber energi. Penelitian ini tidak menggunakan tambahan karbohidrat sehingga motilitasnya tidak lebih baik.

Penyebab tingginya persentase viabilitas dibandingkan motilitas spermatozoa dalam penelitian ini karena yang dinilai progresif adalah motilitas, sedangkan viabilitas adalah persentase hidup mati spermatozoa. Motilitas terjadi akibat adanya kontraksi serabut-serabut yang ada di bagian ekor sehingga dengan pewarnaan mungkin saja tidak menyerap warna, tetapi secara fungsional ekor sudah rusak. Ekor yang rusak pada spermatozoa diindikasikan bahwa spermatozoa masih hidup tetapi mengalami penurunan motilitas.

Dari hasil penelitian ini dapat diambil kesimpulan bahwa volume dan konsentrasi spermatozoa ayam merawang lebih tinggi dibandingkan ayam SK kedu dan kampung. Penambahan antioksidan astaxanthin dan glutathione tidak memengaruhi kualitas semen cair ayam yang disimpan pada suhu $4-5{ }^{\circ} \mathrm{C}$ selama 60 jam. Astaxanthin 0,004\% lebih baik dibandingkan dengan astaxanthin 0,005\%, glutathione 0,007\%, dan glutathione $0,008 \%$. Penyimpanan semen cair dalam pengencer RL-KT dengan motilitas mencapai 40\% berada pada 24-36 jam. Penambahan astaxanthin dan glutathione tidak diperlukan untuk semen cair.

"Penulis menyatakan tidak ada konflik kepentingan dengan pihak-pihak yang terkait dalam penelitian ini"

\section{DAFTAR PUSTAKA}

Alkan S, Baran A, Ozdas BO, Evecen M. 2001. Morphological defects in turkey semen. Journal of Veterinary and Animal Science. 26:1087-1092.

Ambati RR, Phang SM, Ravi S, Aswathanarayana RG. 2014. Astaxanthin: Source, Extraction, Stability, Biological Activities and Its Commercial Applications. Marine Drugs Review. 12:128-152.

Arifiantini I, Yusuf TL, Graha N. 2005. Recovery rate dan Longivitas pasca thawing semen beku sapi $\mathrm{FH}$ (Friesian Holstein) menggunakan berbagai bahan pengencer. Buletin Peternakan. 29 (2):53-61.

Bebas W, Pemayun TGO, Damriyasa IM, Astawa INM. 2016. Lactose-astaxanthin increase Green Jungle Fowl's sperm motility and reduces sperm DNA fragmentation during 50 celcius storage. Bali Medical Journal. 3:152-156.
Chatterjee S, Lamirande ED, Gagnon C. 2001. Cryopreservation alters membrane sulfhydryl status of bull spermatozoa: protection by oxidized glutathione. Molecular Reproduction and Development. 60:498-506.

Comhaire FH, Garem YE, Mahmoud A, Eertmans F, Schoonjans F. 2005. Combined conventional/ antioxidant "astaxanthin" treatment for male infertility: a double blind, randomized trial. Asian Journal of Andrology. 7(3):257-262.

Diwyanto K, Zainuddin D, Sartika T, Rahayu S, Djufri, Arifin C, Cholil. 2011. Model pengembangan peternakan rakyat terpadu berorientasi agribisnis: komoditas ayam lokal. Bogor (ID): Direktorat Jenderal dengan Balitnak Ciawi.

Donoghue AM, Wishart GJ. 2000. Storage of poultry semen. Animal Reproduction Science. 62:213-232.

Farzan M, Chamani M, Varnaseri H. 2014. The antioxidant effect of astaxanthin on quantitative and qualitative parameters of bull sperm. Indian Journal of Foundamental and Applied Life Sciences. 4(4):425-430.

Getachew T. 2016. A Review Article of Artificial Insemination in Poultry. World Veterinary Journal. 6(1):25-33.

Malik A, Haron AW, Yusoff R, Nesa M, Bukar M, Kasim A. 2013. Evaluation of the ejaculate quality of the red jungle fowl, domestic chicken, and bantam chicken in Malaysia. Turkish Journal Veterinary Animal Science. 37:564-568.

Octa IGNAD, Trilaksana IGNB, Bebas W. 2014. Glukosa-astaxanthin meningkatkan motilitas dan daya hidup spermatozoa ayam kampung yang disimpan pada suhu 3-50 C. Indonesia Medicine Veterinary. 3(1):9-19.

Rahayu IHS, Suherlan I, Supriatna I. 2005. Kualitas telur tetas ayam merawang dengan waktu pengulangan inseminasi buatan yang berbeda. Journal of the Indonesian Tropical Animal Agriculture. 3:30-33.

Rakha BA, Ansari MS, Hussain I, Malik MF, Akhter S and Blesbois E. 2015. Semen characteristics of the Indian Red Jungle Fowl (Gallus gallus murghi). European Journal Wildlife Research. doi:10.1007| s10344-015-0904-x.

Rizal M, Herdis. 2010. Peranan antioksidan dalam meningkatkan kualitas semen beku. Wartazoa. 20: 3-6.

Saleh DM, Sugiyatno. 2007. Pengaruh Aras Glycerol terhadap motilitas dan fertilitas spermatozoa ayam kampung yang dibekukan dengan nitrogen cair. Animal Reproduction. 9:1-6. 
Siudzinska A, Lukaszewick E. 2008. Efect of semen extenders and storage time on sperm morphology of four chicken breeds. Applied Poultry Research. 17:101-108.

Sopiyana S, Iskandar S, Susanti T, Yogaswara D. 2006. Pengaruh Krioprotektan DMA, DMF dan glycerol pada proses pembekuan semen ayam kampung. Seminar Nasional Teknologi Peternakan dan Veteriner.

Syarifuddin A, Laksmi DNDI, Bebas W. 2012. Efektivitas penambahan berbagai konsentrasi glutathione terhadap daya hidup dan motilitas spermatozoa sapi bali. Indonesia Medical Veterinary. 1(2):173-185.

Tabatabaei S, Batavani RA, Talebi AR. 2009. Comaprison of semen quality in Indigenous and Ross Broiler breeders roosters. Journal of Animal and Veterinary Advance. 8(1):90-93.

Thananurak P, Sittikasamkit C, Vongpralub T, Sakwiwatkul K. 2015. Effects of Addition of Reduced Glutathione to Thawing media on Motility
Parameters, Lipid Peroxidation and Fertility Rate in Frozen-Thawed Chicken Sperma-tozoa. Khon Kaer Agriculture Journal. 2:43-46.

Tuncer PB, Kinet H, Ozdogan N and Demiral O. 2006. Evaluation of some spermatological characteristics in Denizli cocks. Journal of Faculty of Veterinary Medicine. 3:37-42.

Uysal O, Bucak MN. 2007. Effects of oxidized glutathione, bovine serum albumin, cysteine and lycopene on the quality of frozen-thawed ram semen. Acta Veterinaria. 76:383-390.

Whitaker BD, Carle B, Mukai T, Simpso A, Vu L, Kight JW. 2008. Effect of exogenous glutathione supplementation on motility, viability, and DNA integrity of frozen-thawed boar semen. Animal Reproduction. 5:127-131.

Wiyanti DC, Isnaini N, Trisunuwati P. 2013. Pengaruh lama simpan semen dalam pengencer $\mathrm{NaCl}$ fisiologis pada suhu kamar terhadap kualitas spermatozoa ayam kampung (Gallus domesticus). Jurnal Kedokteran Hewan. 7:53-55. 